\title{
A Model of Entrepreneurial Autonomy in Franchised Outlets: A Systematic Review of the Empirical Evidence
}

\section{Olufunmilola (Lola) Dada}

Department of Entrepreneurship, Strategy and Innovation Lancaster University Management School, UK, LA1 4YX

Email: 1.dada@lancaster.ac.uk. comments.

An earlier version of this article was presented at the Institute for Small Business and Entrepreneurship (ISBE) Conference (2014). 


\title{
A Model of Entrepreneurial Autonomy in Franchised Outlets: A Systematic Review of the Empirical Evidence
}

\begin{abstract}
Entrepreneurial autonomy amongst franchisees is a persistent management challenge. Empirical synthesis is lacking on its drivers, its consequences, and how it can be integrated with the standardization requirements in franchise systems. Various theoretical and empirical studies have stressed that merging franchisee autonomy with the franchisor's desire for uniformity is extremely difficult. This paper aims to provide a systematic review of the relevant empirical studies in order to identify a range of influences, controls, outcomes, and associated moderating and mediating factors which offer a better representation of what contributes to the understanding of franchisee entrepreneurial autonomy. By drawing together findings from a broad range of theoretical perspectives, the evidence was used to develop a comprehensive model of entrepreneurial autonomy in franchised outlets. The model does not only provide a structure that brings together prior studies but also identifies the less researched areas that can advance the management literature on the notion of autonomy in franchising. The research and practitioner implications of the review, as well as its limitations and possible directions for future studies, are discussed.
\end{abstract}

Keywords: Entrepreneurial autonomy, franchising, franchisor, franchisee

\section{Introduction}

Although the entrepreneurial autonomy of the franchisor is undisputed, studies relating to franchisee entrepreneurial autonomy have been split, complicated and continue to be strongly debated (e.g. Darr et al. 1995; Gassenheimer et al. 1996; Bradach 1997; Kaufmann and Eroglu 1998; Sorenson and Sørensen 2001; Yin and Zajac 2004; Barthélemy 2008; Davies et al. 2011; Zachary et al. 2011; Dada and Watson 2012, 2013; Nijmeijer et al. 2014; Evanschitzky et al. 2016; Watson et al. 2016). As entrepreneurial autonomy and franchising are diametrically opposed concepts, many have questioned how entrepreneurial autonomy amongst franchisees can be aligned with the standardization requirements on which the franchise system is built (for discussions, see Kaufmann and Eroglu 1998; Dant and Gundlach 1999; Birkeland 2002; Pizanti and Lerner 2003; Clarkin and Rosa 2005; Paik and Choi 2007; Hoy 2008; Ketchen et al. 2011; Dada et al. 2012; López-Bayón and LópezFernández 2016). There has been no known attempt to juxtapose empirical findings to produce a systematic review as to how franchisee entrepreneurial autonomy is positioned in 
terms of relevance. The present paper aims to address this gap in the literature by providing a systematic review of empirical studies in order to identify a range of influences, controls, outcomes, and moderating and mediating factors, which offer a better representation of what contributes to the understanding of franchisee entrepreneurial autonomy.

Autonomy is an established concept in the management literature (Lumpkin et al. 2009). "In an organizational context, it refers to action taken free of stifling organizational constraints” (Lumpkin and Dess 1996: 140). Although several types of autonomy have been conceptualized (e.g. Langfred 2004, 2005; Caza 2012), the present paper focuses on 'entrepreneurial' autonomy, which underpins many of the management challenges in franchising ${ }^{1}$. Drawing on Lumpkin et al. (2009), franchisee entrepreneurial autonomy is here defined as the extent to which franchisees are able to exercise independence of thoughts and actions to operate freely outside the standardized confines of the franchise system. It could be argued that franchisee entrepreneurial autonomy can lead to improved performance, as autonomy when it occurs in the form of franchisee innovation can benefit the franchisor, in terms of increased local market adaptability and increased chain-wide innovation (Combs et al. 2004b). However, franchisee entrepreneurial autonomy is widely frowned upon as it can lead to franchisee non-compliance (Weaven et al. 2010; Davies et al. 2011); deviation from the franchisor's proven standards (Cox and Mason 2007); franchisee free riding (Kidwell et al. 2007); loss of corporate identity, trademark erosion and quality deterioration (Cox and Mason 2007; Paik and Choi 2007).

It is therefore evident that the notion of franchisee entrepreneurial autonomy raises several questions. The major contribution of the present review is the building of a comprehensive model which draws together empirical evidence from diverse theoretical

\footnotetext{
${ }^{1}$ This article focuses on business format franchising, which "occurs when a firm (the franchisor) sells the right to use its trade name, operating systems, and product specifications to another firm (the franchisee)" (Castrogiovanni et al. 2006: 27-28).
} 
perspectives to identify the core factors and the associated secondary factors that are important for understanding franchisee entrepreneurial autonomy.

Two notable reviews on franchising have appeared recently in the management literature - the papers by Combs et al. (2011) and Nijmeijer et al. (2014). Combs et al.'s (2011) review focused on recent insights about franchising, its causes, its effects and factors that shape these relationships, as well as the implications of a multidisciplinary perspective for franchising research. In the other review by Nijmeijer et al. (2014), they focused on collecting all the empirical evidence on the factors that make franchising work and to bring this evidence together in an integrative framework. Unlike both of these studies which have a broad focus, the present review differs in that it focuses on one persistent management challenge in franchising, i.e., franchisee entrepreneurial autonomy. This gap in our understanding is important because franchisee entrepreneurial autonomy goes against the essence of franchising, which is centred on uniform replication of the franchisor's proven business concept in different locations (Dada et al. 2012; Dada and Watson 2012, 2013).

In the next section of the paper, the methodology adopted for the review is discussed, prior to presenting the results. The implications, limitations, directions for future research, and conclusion of this review are discussed in the final sections of the paper.

\section{Methodology}

This paper employed a systematic literature review methodology (Cook et al. 1997; Tranfield et al. 2003; Denyer and Neely 2004; Pittaway et al. 2004; Thorpe et al. 2005) which focused on identifying key scientific contributions, and developing an evidence base that exceeds those of a single study (Hakala 2011). This methodology was suitable because it enabled development of a reliable knowledge stock by synthesizing prior research in a transparent and scientific manner (Tranfield et al. 2003). It addresses weaknesses of traditional narrative 
reviews which have been criticized for lack of rigor, as the selection of studies for inclusion are subject to researchers' bias (Tranfield et al. 2003).

\section{Data collection}

(i) Inclusion criteria. To determine the studies to include in this review, three categories of inclusion criteria were employed, following Wang and Chugh (2014). These comprised determining the search boundaries, identifying the search terms, and specifying the coverage period. First, the search boundaries were set as electronic databases namely, ABI/INFORM Complete (ProQuest), Business Source Premier, JSTOR, ScienceDirect, Web of Science and Wiley Online Library. Second, the search terms identified were the dominant additional terminologies utilized in the literature to capture franchisee entrepreneurial autonomy. These were franchisee independence, innovation, creativity, invention, adaptation, new ideas, new opportunities, initiatives, flexibility, entrepreneurial orientation, entrepreneurial behavior, entrepreneurial activity and entrepreneurship (e.g. Darr et al. 1995; Gassenheimer et al. 1996; Bradach 1997; Sorenson and Sørensen 2001; Yin and Zajac 2004; Barthélemy 2008; Akremi et al. 2011; Davies et al. 2011; Dada et al. 2012; Dada and Watson 2012, 2013; Nijmeijer et al. 2014). Third, the search coverage period encompassed articles published up to December 2013.

(ii) Search strategy. The Title and Abstract fields of the above electronic databases were searched, similar to Wang and Chugh (2014), as these fields typically contain the keywords. ${ }^{2}$ The search was undertaken for publications in peer-reviewed academic journals that had full texts and which were written in English. Consistent with many systematic reviews, only

\footnotetext{
${ }^{2}$ Web of Science does not have an Abstract in its Field Tags. Therefore, the Web of Science search involved only the Title field.
} 
journal articles were included because of the ranking of evidence from these knowledge sources. As noted by Keupp et al. (2012: 369), “journal articles can be considered validated knowledge and are likely to have the highest impact on the field”. The search terms in the above sub-section were employed in the electronic databases to obtain articles published up to December 2013. Truncation was used in the search terms to find all relevant articles that had variants of the words i.e. the search contained franchis* AND each of the following words consecutively: autonom*, independ*, innovat*, creat*, invent*, adaptat*, new*, idea*, opportunit*, initiat*, flexib* and entrepreneur*. To ensure that no relevant study was omitted, the reference lists of the selected articles were checked, searches using variants of the keywords were undertaken in Google Scholar, and a final broader search for articles that had variants of franchise in their titles was conducted in the above electronic databases by using franchis* as a general search term. The overall search strategy generated an initial sample comprising 1,071 articles.

(iii) Exclusion criteria. The above initial sample was subject to further evaluation based on the following exclusion criteria. First, duplicates were removed. Then, non-empirical articles were excluded because the focus of this review was on empirical literature, i.e. studies that were based on data collection and analysis, and that used either quantitative and/or qualitative methods. Articles that were not based on business format franchising, which is the focus of this study, were excluded (these included articles on product distribution franchising, rail franchises and sports franchises). Articles that just had reference to franchise but which were not focused on research within the franchising context were removed. Also excluded were articles that focused on international franchising alone. This is because unlike franchising within a domestic market, expansion through international franchising requires different dynamics (Nijmeijer et al. 2014). With regards to franchisee entrepreneurial autonomy, the 
environmental differences in international contexts may drive the need for substantial adaptations in order for the business model to be viable (Winter et al. 2012). Finally, articles that were not applicable to this study's aim were excluded (although the search terms were present, the discussions in these articles were not focused on franchisee entrepreneurial autonomy). These exclusion criteria led to a final sample of 49 articles that was utilized for the systematic review.

\section{Data analysis}

Content analysis was used to analyze the data, consistent with several systematic literature reviews (e.g. Sirola-Karvinen and Hyrkäs 2006; Engström et al. 2007; Davey et al. 2009; Germain and Cummings 2010). Recent years have seen widespread acceptance of studying management knowledge via systematic reviews of academic journals using content analysis (Cetindamar et al. 2009), which has been defined as "the systematic, objective, quantitative analysis of message characteristics” (Neuendorf 2002: 1). Content analysis is a powerful data reduction technique for analyzing large bodies of text (Stemler 2001; Prasad 2008). It involves "establishing categories and systematic linkages between them, and then counting the number of instances when those categories are used in a particular item of text" (Silverman 2013: 443). This aids identification of dominant findings and generalizations (Mays et al. 2005).

The content analysis in this review was undertaken manually. First, the (content) categories were identified and defined in terms of the aim of the study (Prasad 2008). Developing the categories to be used for classification is central to content analysis; this can be done via preliminary examination on a small-scale (Prasad 2008). To enhance reliability, half of the papers in the final sample were initially analyzed in order to develop the categories (Heeks and Bailur 2007). These were the papers deemed to have had the highest impact, in 
terms of the number of citations derived from Google Scholar. The development of the categories was iterative as they were slightly revised, and a few more categories included, after reading the entire articles in the final sample (Stemler 2001; Heeks and Bailur 2007). By evaluating all the 49 papers in order to determine the final categories, it was possible to control for biases. Overall, the selected studies were classified into main categories and subcategories (Sirola-Karvinen and Hyrkäs 2006). Second, the units of analysis (i.e. the smallest units of content that were to be coded into the main categories and sub-categories) were decided: these comprised words or terms, themes and concepts (Berg 2001; Prasad 2008). Third, the units of analysis were coded into the main and sub-categories, based on their common characteristics (Cummings et al. 2010). As an example, 'positive outcomes' is a main category; 'financial and non-financial performance' is a sub-category of positive outcomes. Units of analysis such as 'performance of the franchise network', 'network performance', and 'performance outcomes of franchise systems' which appeared in the articles by Dada et al. (2012), Dada and Watson (2013), and Gorovaia and Windsperger (2013) were coded into the aforementioned main and sub-categories. Finally, the quantification of the units of analysis was undertaken by using the number of times a given unit of analysis appeared in a body of text within the selected articles (Prasad 2008). To enable the development of a theoretical model, visual maps were utilized to graphically depict the emerging patterns of relationships (Whetten 1989; Zerbinati and Souitaris 2005). An example of this was the creation of 4 large diagrams - similar to Figure 1 (which is discussed below) - and articles were allocated into their respective positions in the diagrams.

\section{Results - the state of the empirical literature}

Table 1 (see the Appendix) presents a description of the articles in the final sample in chronological order. It shows that relevant studies were published over a period of 18 years 
(1995-2013). The start year for publications coincides with when scholars increasingly started promoting franchising as an entrepreneurial organizational form, countering the assumption that it is the antithesis of entrepreneurship (Shane and Hoy 1996; Hoy and Shane 1998; Kaufmann and Dant 1999).

The articles in Table 1 were published in journals in diverse domains such as, management, organization studies, strategy, marketing, entrepreneurship, economics and tourism. Majority of the studies utilized quantitative research designs $(n=30)$, consistent with arguments that most franchising studies use quantitative methods (Cox and Mason 2009). Qualitative research designs were employed in 13 articles, and 6 articles used mixed methods (i.e. quantitative and qualitative). Although prior studies collected data from diverse industry sectors, the food industry sector was dominant ( $\mathrm{n}=25)$. The US (and North America) were the most researched in terms of regional focus $(n=19)$.

As shown in Table 1, various theoretical perspectives were used in the articles. The most frequently used perspective was agency theory, employed in 23 studies (47\% of the sample). This was followed by resource-based theory. These findings are consistent with arguments that agency and resource-based perspectives have been dominant in franchising research (Combs et al. 2004b; Combs et al. 2009; Gillis et al. 2011). From an agency perspective, franchising research examines a contractual relationship wherein the franchisor (principal) must delegate authority to the franchisee (agent) (Combs and Ketchen 1999; Paik and Choi 2007). Agency theory underpins the literature on franchisee entrepreneurial autonomy perhaps because franchisor and franchisee tend to have different goals, which can create possibilities for franchisees to act autonomously according to their self-interests (see e.g. Paik and Choi 2007; Gillis et al. 2011). This makes franchising relationships problematic as it can result in negative opportunistic behaviors by the franchisee (Akremi et al. 2011). On the other hand, the premise of resource-based perspective is on the resources that franchisors 
can obtain from franchisees (Combs et al. 2011). It suggests that franchisors use franchising to leverage franchisees’ capital, and managerial and local knowledge (Combs et al. 2011). In this review, resource-based perspective includes resource dependence theory; the latter suggests that the franchisor and the franchisee mutually need each other to achieve profits (Paik and Choi 2007). Despite the differences between agency theory and resource-based theory, both are similar in that they demonstrate franchisees' entrepreneurial role in the franchisor-franchisee relationship, indicating relevance to the study of franchisee entrepreneurial autonomy. According to agency theory, franchisors are in partnership with independent entrepreneurs (i.e. franchisees) who invest their own capital in their franchised outlets, are self-motivated, and exhibit self-enforced effort (Barthélemy 2011; Meek et al. 2011). Likewise, resource-based perspective depicts franchisees as providers of resources e.g. entrepreneurial resources via their local decision-making and their informational capital from local markets - which can facilitate rapid growth in franchise systems (Combs et al. 2004b; Combs et al. 2011; Dada et al. 2012).

In addition to the two prevalent theories (i.e. agency theory and resource-based theory), other theoretical perspectives utilized in the articles included contingency theory, property rights theory, transaction cost theory, learning perspective, organizational identity theory, channel theory, and many others. Twenty two studies utilized more than one theoretical perspective, 19 studies used only one theoretical perspective, and the theoretical perspectives employed were unknown in 8 studies. The level/unit of analysis (i.e. the respondent perspective utilized for analysis) were the franchisee, the franchisor and others. Most of the studies employed only one level/unit of analysis, while others used more than one level/unit of analysis. 


\section{Results - a model of factors associated with franchisee entrepreneurial autonomy}

The review identifies components of, and relationships between, five core factors associated with franchisee entrepreneurial autonomy: (1) the positive and negative outcomes (2) control mechanisms (3) the external and internal influencing factors (4) the internal moderators and (5) the internal mediator. These are presented in Figure 1 and the findings are discussed below.

\section{INSERT FIGURE 1 ABOUT HERE}

\section{The positive and negative outcomes}

Evidence from the review shows two broad categories of outcomes of franchisee entrepreneurial autonomy for franchisors and franchisees. ${ }^{3}$ The first category comprises the positive outcomes; the second category comprises the negative outcomes.

(i) Positive outcomes. The benefits of franchisee entrepreneurial autonomy were reported in 17 studies (Darr et al. 1995; Hing 1995; Strutton et al.1995; Gassenheimer et al. 1996; Bradach 1997; Jambulingham and Nevin 1999; Pizanti and Lerner 2003; Yin and Zajac 2004; Cox and Mason 2007; Weaven and Herington 2007; Flint-Hartle and de Bruin 2011; Gillis et al. 2011; Dada et al. 2012; Dada and Watson 2012, 2013; Gorovaia and Windsperger 2013; Melo et al. 2013).

Six studies (Gassenheimer et al. 1996; Yin and Zajac 2004; Gillis et al. 2011; Dada et al. 2012; Dada and Watson 2013; Gorovaia and Windsperger 2013) suggest that franchisee entrepreneurial autonomy is positively related to the financial and non-financial performance of franchisors $(n=5)$ and franchisees $(n=1)$. Most of these studies employed agency and

\footnotetext{
${ }^{3}$ For consistency, the outcomes for franchisors reported in the present paper also include outcomes for the franchise system, franchise chain, franchise network and franchise organization.
} 
resource-based theories, where these theoretical approaches collectively suggest that agents (franchisees) provide value to the franchise system as they are a source of entrepreneurial resources. Both resource-based and agency theories were equally informative in relation to understanding the positive outcomes of franchisee entrepreneurial autonomy, with neither theory being superior to the other. The studies were conducted in the UK $(n=2)$, US $(n=2)$ and Germany $(\mathrm{n}=1)$; one study used US and Canadian data. Only one study was based on multiple (i.e. 13) industry sectors; one study focused on the property services sector; three studies were based on the restaurant and fast-food sectors; and one study was conducted within the product/distribution and service sector. Four studies employed quantitative methods; one study used a qualitative method; and one study employed both quantitative and qualitative methods. Taken together, the findings from all the studies suggest that franchisee entrepreneurial autonomy may be a mechanism for enhancing franchise system performance. Relative to the other studies, the qualitative findings from Dada et al. (2012) provided further deeper insights, which showed that the resultant positive performance outcomes aligned with franchisees' motivations for entrepreneurial autonomy; the motivations were mainly the pursuit of better returns and for franchised outlets' success. The authors also found that the positive performance outcomes aligned with why franchisors seem to desire franchisee entrepreneurial autonomy, in terms of the benefits for franchise system growth.

The review further indicates that franchisee entrepreneurial autonomy generates system-wide adaptations (Darr et al. 1995; Bradach 1997; Cox and Mason 2007; Weaven and Herington 2007; Dada et al. 2012; Melo et al. 2013), organizational learning (Bradach 1997; Weaven and Herington 2007) and competitive advantage (Flint-Hartle and de Bruin 2011). With most of these studies based on agency and resource-based theories, both perspectives suggest that franchisees in their role as agents provide resources for franchisors in the form of new knowledge often arising from franchisees’ local markets. Again, both agency theory and 
resource-based theory were suitable in these contexts. The studies that reported these franchisor benefits were conducted in the US $(n=2)$, UK $(n=2)$, Australasia $(n=2)$ and Brazil $(n=1)$. Most of these studies employed qualitative methods $(n=5)$; only two studies used a combination of quantitative and qualitative methods. One study was based on multiple (i.e. 6) industry sectors; three studies were conducted within the restaurant, food and fast-food sectors; two studies were based on the property and the real estate brokerage sectors; and one study was undertaken within the services sector.

Evidence from three studies (Hing 1995; Gassenheimer et al. 1996; Jambulingham and Nevin 1999) indicates that franchisee entrepreneurial autonomy enhances franchisee satisfaction with the franchisor and contributes to franchisees' post-purchase satisfaction. Additionally, four studies (Strutton et al. 1995; Jambulingham and Nevin 1999; Pizanti and Lerner 2003; Dada and Watson 2012) found that franchisee entrepreneurial autonomy has a positive influence on franchisor-franchisee relationship, including the degree of cooperation and solidarity between the franchise partners. Two of these studies draw on agency theory (i.e. Jambulingham and Nevin 1999; Pizanti and Lerner 2003), indicating that franchisees that are granted autonomy, and those franchisees who have perceptions of autonomy, view the relationship they have with their franchisors as a cooperative partnership. All the aforementioned positive outcomes were consistent regardless of the respondent perspectives utilized for the analysis; one study used the franchisor perspective, three studies were based on the franchisee perspective, one study employed the franchise chain and one study used both the franchisor and the franchisee perspectives. Overall, these findings suggest that franchisee entrepreneurial autonomy has positive effects on franchisor-franchisee relationship quality. Perhaps this is because autonomy enhances franchisees' motivation to operate their outlets (Pizanti and Lerner 2003). Indeed, Jambulingham and Nevin’s (1999: 378) findings demonstrate that franchisee entrepreneurial autonomy reduces franchisee opportunism i.e. 
"the extent to which the franchisees act in self-interest in order to achieve their own goals despite possible damage to their franchisors". Relational exchange-based theory was the most applied perspective in all the studies here, and the positive outcomes match the emphasis on human interactions suggested by exchange theory (Pizanti and Lerner 2003).

(ii) Negative outcomes. Despite the positive outcomes reported above, adverse effects of franchisee entrepreneurial autonomy were reported in four studies for both the franchisee and the franchisor (Jambulingham and Nevin 1999; Weaven and Herington 2007; Weaven et al. 2010; Winter et al. 2012). Irrespective of the country of study, the sectors used for the sample and the methodologies employed, the results suggest that franchisee entrepreneurial autonomy increases the risk of franchisee failure, leads to conflict with the franchisor, results in losses in scale economies and increases franchisee opportunism. The later findings in relation to franchisee opportunism was reported by Jambulingham and Nevin (1999); the results indicate that franchisee opportunism can be a positive effect (as shown above in the discussions of the positive outcomes) or a negative outcome (as shown in the present section), depending on the conceptualization of franchisee entrepreneurial autonomy. When franchisee entrepreneurial autonomy was measured as franchisees with higher perceived innovativeness, this was found to reduce franchisee opportunism (i.e. a positive outcome). Conversely, when franchisee entrepreneurial autonomy was measured as franchisees who perceive themselves to be risk-takers, this was found to increase franchisee opportunism (i.e. a negative outcome). In general, negative outcomes may occur possibly because franchisee entrepreneurial autonomy can be associated with deviation from the franchisor's template and directives, putting strain on the franchisor-franchisee relationship (Weaven et al. 2010; Winter et al. 2012). In relation to the negative outcomes, agency theory was the most applied 
perspective, suggesting that franchisee entrepreneurial autonomy can increase agency costs to the franchisor (Jambulingham and Nevin 1999).

\section{Control mechanisms}

The positive and negative outcomes point toward the need to understand how franchisee entrepreneurial autonomy can be managed. The review revealed a wide range of mechanisms used to control franchisee entrepreneurial autonomy. Control mechanisms in franchising are used to protect the brand name, which is an intangible and essential asset, and to ensure its stability when viewed from customers’ perspective (Pizanti and Lerner 2003).

The control mechanisms, reported in 11 studies (Bradach 1997; Clarkin and Rosa 2005; Cox and Mason 2007; Weaven and Herington 2007; Cochet and Garg 2008; Cochet et al. 2008; Akremi et al. 2011; Flint-Hartle and de Bruin 2011; Dada et al. 2012; Winter et al. 2012; Melo et al. 2013), can be categorized into two broad types: (i) the formalized control mechanisms exercised by franchisors and (ii) the formalized and social control mechanisms exercised by franchisees. Majority of these were exercised by franchisors, with franchisees exercising control mechanisms only in a few cases.

(i) The formalized control mechanisms exercised by franchisors include the use of franchise contract and incentives as guide for, and to restrict, franchisee entrepreneurial autonomy (Bradach 1997; Clarkin and Rosa 2005; Cochet and Garg 2008; Dada et al. 2012); the presence of franchise coordinators and franchise managers from the franchisor headquarters in franchisee networks (Dada et al. 2012); freedom for franchisees to innovate with the franchisor's permission (Clarkin and Rosa 2005); the need for franchisee innovations to follow the franchisor's guidelines (Dada et al. 2012; Melo et al. 2013); monitoring of franchisee adaptations and excessive deviations (Weaven and Herington 2007; Winter et al. 
2012); the existence of strictly circumscribed sphere where franchisee entrepreneurial behaviors are allowed to take place (Cox and Mason 2007; Dada et al. 2012); the use of franchisor mechanisms to capture innovations that assist competitive advantage (Flint-Hartle and de Bruin 2011); franchisor learning to vigilantly identify, understand, and correct franchisee deviations (Bradach 1997); and the franchisor's use of relational forms of governance more intensely where franchisees possess more autonomy, and thus have more room for opportunistic behavior (Cochet et al. 2008). Although multiple theories were utilized in the studies reported here, agency theory was predominant. The use of agency theory may suggest that franchisors utilize control mechanisms to create boundaries for franchisee entrepreneurial behaviors, in order to minimize potential undesirable consequences (i.e. agency costs).

(ii) The formalized and social control mechanisms exercised by franchisees were reported in two studies (Akremi et al. 2011; and Dada et al. 2012). The formalized mechanisms involved franchisee representatives, who acted as 'the voice of the other franchisees', in communicating franchisee initiatives to the franchisor (Dada et al. 2012). These were initiatives from franchisee autonomy that were being considered for implementation. Franchisees' social control mechanism involved using cohesion among themselves to decrease franchisee deviation from standards (Akremi et al. 2011). This suggests that although agency theory assumes that the franchisor (principal) can solely control franchisee autonomy, franchisees (agents) may utilize social mechanisms amongst themselves to control their autonomy (Akremi et al. 2011). 


\section{Influencing factors}

The review indicates two types of factors- external and internal- that influence franchisee entrepreneurial autonomy. The external factors comprise industry effect, local conditions and local market variations; while the internal factors consist of those from the franchisor and the franchisee’s perspectives.

(i) External factors. The effect of environmental forces on franchisee entrepreneurial autonomy was reported in 9 studies (Bradach 1997; Dant and Gundlach 1999; Sorenson and Sørensen 2001; Pizanti and Lerner 2003; Paik and Choi 2007; Flint-Hartle and de Bruin 2011; Hussain and Windsperger 2011; Dada et al. 2012; Mumdžiev and Windsperger 2013).

Industry effect was reported in Flint-Hartle and de Bruin (2011) which found that acculturation (i.e. assimilation in the first instance into the culture of the industry and then that of the franchisor) allows franchisee autonomy in business operation, and the franchise system benefits from the resulting innovative practices.

Qualitative studies conducted in the US and the UK, by Bradach (1997) and Dada et al. (2012) respectively, indicate that competition leads to high levels of franchisee entrepreneurial autonomy. These findings differ from the quantitative study conducted in the US by Dant and Gundlach (1999), and the qualitative study undertaken in the US and multiple European countries by Paik and Choi (2007) which found that within a franchise setting, higher levels of competition will lead to lower levels of franchisees' desire for autonomy.

In all, the evidence suggests that competition has different impact on franchisors and franchisees. When faced with high levels of competition, franchisees use entrepreneurial autonomy to respond to competitors (Bradach 1997; Dada et al. 2012). On the other hand, with intense competition, franchisors will be prompted to exercise more control because 
franchisees may be revealing more information than usual to their franchisors, implying the franchisees less desire for autonomy (Dant and Gundlach 1999; Paik and Choi 2007). Indeed, Mumdžiev and Windsperger (2013) found that environmental uncertainty has a negative effect on the delegation of decision rights to franchisees. This implies that when franchisors perceive higher market and demand uncertainty, they impose higher control over local outlet decisions, hence reducing franchisees' influence on decision making (Mumdžiev and Windsperger 2013).

Evidence from Bradach (1997), Pizanti and Lerner (2003) and Hussain and Windsperger (2011) suggests that franchisees demonstrate entrepreneurial autonomy in response to the demands and requirements of their local markets. This mainly entails adapting their product lines and proposing products that were sometimes adopted throughout the franchise system (Bradach 1997; Hussain and Windsperger 2011). These findings are consistent with those of Sorenson and Sørensen (2001) that franchisees adapt to environmental opportunities because they operate under strong incentives to maximize local, long-term performance.

The findings in terms of agency theory, which was the most used perspective here, may indicate that franchisees continually look for means to improve their businesses (Bradach 1997), which often involves displaying entrepreneurial behaviors by seeking new opportunities (Dada et al. 2012). Resource-based theory, which was the second most applied perspective here, further complements the agency-based inferences. Since franchisees in their role as agents are likely to be more familiar with local market conditions relative to the franchisor (Cox and Mason 2007), resource-based explanations suggest that this familiarity can influence franchisees to introduce local market knowledge (which is an important entrepreneurial resource) to their systems (see Dada et al. 2012). 
(ii) Internal factors. These are the organizational forces from the franchisor's and the franchisee’s perspectives that drive franchisee entrepreneurial autonomy.

(a) The influence of the franchisor-drivers on franchisee entrepreneurial autonomy was reported in 18 studies (Bradach 1997; Falbe et al. 1999; Dickey and Ives 2000; Pizanti and Lerner 2003; Yin and Zajac 2004; Clarkin and Rosa 2005; Cox and Mason 2007; Paik and Choi 2007; Weaven and Herington 2007; de Azevedo 2009; Flint-Hartle and de Bruin 2011; Mumdžiev and Windsperger 2011; Zachary et al. 2011; Dada et al. 2012; Winter et al. 2012; Berkowitz and Wren 2013; Dada and Watson 2013; Mumdžiev and Windsperger 2013).

The findings from Falbe et al. (1999), Pizanti and Lerner (2003) and Zachary et al. (2011) suggest that the franchisor's firm size will have a positive influence on franchisee entrepreneurial autonomy. This may be linked to the level of franchisor support for franchisee entrepreneurial autonomy in large firms. Falbe et al. (1999) found that large franchisor size was positively related to management support for franchisee innovation, including recognition. Indeed, franchisor support- which can occur in various forms e.g. via methods instituted to encourage entrepreneurial activity in franchised outlets- was reported to have a positive influence on franchisee entrepreneurial autonomy in the studies by Bradach (1997), Falbe et al. (1999), Clarkin and Rosa (2005), and Dada and Watson (2013). The findings in relation to agency theory, which was the most applied perspective here, may reflect entrepreneurial teamwork in the franchisor-franchisee relationship (Clarkin and Rosa 2005).

In a study of franchisors and franchisees in North America, Clarkin and Rosa (2005) demonstrate the positive influence of a flexible organizational culture on franchisee entrepreneurial autonomy. This involved a system that facilitates entrepreneurial teamwork between the franchisor and the franchisee, where both partners were free to innovate (Clarkin and Rosa 2005). Berkowitz and Wren (2013) reported findings that are somewhat consistent 
with Clarkin and Rosa (2005). Berkowitz and Wren’s (2013) findings suggest that high levels of centralized control by upper management [i.e. the franchisor's organizational structure] lead to lower levels of local control on the part of franchisees.

The evidence further demonstrates the relationship between age of the franchisor's firm and franchisee entrepreneurial autonomy, based on the fast-food sector. The findings suggest that franchisees operating in franchise organizations that are in the growth stage tend to have more autonomy than those franchisees operating in organizations that are in the mature stage (Paik and Choi 2007). It has been argued that the entrepreneurial activity that characterizes new organizations tends to disappear as organizations grow older; at the older stage, organizations face pressures to increase standardization in order to maintain internal consistency (Falbe et al. 1999). This may explain the negative influence of franchisor age on franchisee entrepreneurial autonomy. Although the direction of influence was not reported in the study by Pizanti and Lerner (2003), it was found that the age of the franchise chain (which may be veteran or new) would have an influence on control and autonomy in the franchisor-franchisee relationship. The findings here suggest that resource-based theory may be better than agency theory in explaining why franchisees have more autonomy when their franchisor organizations are in the growth stage. This is because in the growth stage, franchisors rely on franchisees' expertise to help develop the business, consistent with resource-based theory (unlike agency theory which focuses on the franchisor's use of coercive power) (Paik and Choi 2007). Resource-based theory suggests that this reliance may create a strong collaboration between the franchisor and the franchisee (Paik and Choi 2007).

In addition, based on organizational identity theory, Zachary et al.'s (2011) findings suggest that higher-performing franchisors can have a positive influence on franchisee entrepreneurial autonomy. In order to attract potential franchisees, it was found that these franchisors use rhetoric indicative of each dimension of entrepreneurial orientation (namely, 
autonomy, competitive aggressiveness, innovativeness, proactiveness and risk taking) in their recruitment Web sites. These findings suggest that franchisors view franchisees as being similar to entrepreneurs or prefer those franchisees that are entrepreneurs (Zachary et al. 2011). Since a major reason for franchising is to grow the franchise, this may explain why franchisors would attempt to recruit franchisees that would behave more like entrepreneurs than investors (Zachary et al. 2011).

Two studies from the restaurant and services sectors in the US and Australia suggest that the choice of a franchised governance structure (as opposed to a company-owned governance structure) will have a positive influence on franchisee entrepreneurial autonomy (Yin and Zajac 2004; Weaven and Herington 2007). Each of these studies made reference to both agency and resource-based perspectives, which may indicate the complementarities of the two theories in studying franchisee entrepreneurial autonomy. Franchisees provide innovations in franchise systems that adopt a plural governance strategy i.e. organizations using a mix of company-owned and franchisee-owned outlets (Weaven and Herington 2007). ${ }^{4}$ These franchisee innovations can be viewed as outcomes of resources that franchisees provide to the system under the resource-based theoretical explanations. The incentives rationale of agency theory (Weaven and Herington 2007) also indicate that unlike company-owned outlets, franchised outlets are characterized by more decentralized decision rights, greater operational flexibility and stronger financial incentives (Yin and Zajac 2004). These are features associated with local responsiveness and adaptation (Yin and Zajac 2004), which are linked to franchisee entrepreneurial autonomy.

The research conducted in Israel by Pizanti and Lerner (2003), based on findings from a fast-food chain, demonstrates that a complex franchising concept (e.g. in relation to the variety of products/services in the franchised outlets), and a long-term (10-year) franchise

\footnotetext{
${ }^{4}$ Most franchise systems use both franchised and company-owned outlets, which is commonly referred to as the 'plural form' (Bradach 1997).
} 
contract, promotes franchisee autonomy. Autonomy was allowed at every franchised outlet and centralized control was designed to monitor the numerous outlets so as to protect the chain's reputation. These findings indicate that agency theory and exchange theory can be used jointly to understand variations of control and autonomy in franchising relationships, as these perspectives emphasize formal and dynamic aspects of franchisor-franchisee relations (Pizanti and Lerner 2003).

Using agency and property rights theories, the findings from two quantitative surveys of franchise systems in Brazil and Germany suggest that franchisors' intangible assets (e.g. brand name value) will have a negative relationship with franchisee entrepreneurial autonomy (de Azevedo 2009; Mumdžiev and Windsperger 2011). In contrast, franchisees' intangible assets (captured with franchisees' innovation assets) will have a positive relationship with franchisee entrepreneurial autonomy (Mumdžiev and Windsperger 2011). Taken together, these findings demonstrate that if franchisors want less franchisee entrepreneurial autonomy, the focus should be on strengthening franchisors' intangible assets. However, if the franchisor desires more franchisee entrepreneurial autonomy, the focus should be on enhancing franchisees' intangible assets. Protecting the franchisor's strong intangible assets reflects a need to intensify control across the franchised outlets (de Azevedo 2009; Mumdžiev and Windsperger 2011), thus implying less franchisee entrepreneurial autonomy. On the contrary, residual decision rights tend to be delegated to franchisees when they have more intangible assets (i.e. innovation assets) which signifies that the franchisee has (less contractible) local market knowledge that is costly to transfer to the franchisor (Mumdžiev and Windsperger 2011). This indicates more entrepreneurial autonomy for franchisees. Indeed, prior studies suggest that franchisors encourage franchisee entrepreneurial autonomy because of the belief that franchisees might have superior knowledge of their local markets (Winter et al. 2012). 
In another study based on transaction cost theory, Mumdžiev and Windsperger (2013) reported that behavioral uncertainty has a positive effect on the delegation of decision rights to franchisees (e.g. the strength of franchisees' influence on product/service offering). This implies that franchisors tend to delegate decision rights [autonomy] to franchisees when they encounter difficulties in measuring performance of the franchisees and controlling their behavior (Mumdžiev and Windsperger 2013). These findings demonstrate that franchisors may want more franchisee entrepreneurial autonomy when there are high levels of uncertainty in franchisee behavior.

(b) The influence of the franchisee-drivers on franchisee entrepreneurial autonomy was reported in 20 studies (Darr et al. 1995; Dant and Gundlach 1999; Grünhagen and Mittelstaedt 2005; Maritz 2006; Dickey et al. 2007; Paik and Choi 2007; Weaven and Herington 2007; Huang and Phau 2009; Weaven et al. 2009; Weaven et al. 2010; Blut et al. 2011; Davies et al. 2011; Ketchen et al. 2011; Dada et al. 2012; Altinay et al. 2013; Dant et al. 2013a,b; Melo et al. 2013; Paswan and Cheng 2013; Perrigot et al. 2013).

Positive and negative relationships were found between franchisee ownership structures (both single-unit and multi-unit ownership) and franchisee entrepreneurial autonomy (Dant and Gundlach 1999; Grünhagen and Mittelstaedt 2005; Maritz 2006; Paik and Choi 2007; Weaven and Herington 2007; Ketchen et al. 2011). Three studies suggest that franchisees who have multiple outlets are likely to have more entrepreneurial autonomy (Grünhagen and Mittelstaedt 2005; Maritz 2006; Ketchen et al. 2011). This is because they exploit their entrepreneurial ambitions via the expansion of the franchise (Ketchen et al. 2011). It has also been found that multi-unit franchisees attach less importance to dependence on the franchisor (Dant et al. 2013a). These results align with those reported above for the franchisor-drivers in relation to the size of the franchisor's firm having a positive influence 
on franchisee entrepreneurial autonomy. However, in two studies, a negative effect of multiunit ownership on franchisees’ desire for autonomy was found (Dant and Gundlach 1999; Paik and Choi 2007). The explanations for the negative effect were based on arguments indicating that multi-unit franchisees can be viewed as 'mini-franchisors' because they are responsible for the supervision and management of their own chain of outlets (Dant and Gundlach 1999; Paik and Choi 2007). Therefore, multi-unit franchisees appreciate the underlying rationale for imposing franchisor control (Dant and Gundlach 1999; Paik and Choi 2007) which may in turn drive lower desires for entrepreneurial autonomy. In addition, findings from a study where the franchisor was the level of analysis, suggested that singleunit franchisees enjoy entrepreneurial autonomy as they adapt their product and service offerings to meet local demands (Weaven and Herington 2007). This is consistent with resource-based explanations on the franchisee being a source of local market knowledge. Altogether, the findings reiterate the importance of jointly using agency and resource-based perspectives (which were the most applied theories in this instance) when studying franchisee entrepreneurial autonomy.

Three studies (Paik and Choi 2007; Blut et al. 2011; Dada et al. 2012) suggest that the age of the franchisee's firm can influence franchisee entrepreneurial autonomy. In the qualitative studies by Paik and Choi (2007) and Dada et al. (2012), which were based on the fast-food sector and the property services sector respectively, in the US and multiple countries in Western Europe, it was found that experience of the franchisee (i.e. the length of time spent working within the franchise system) positively influences franchisee's level of autonomy. Partial support for the foregoing findings was reported in Blut et al.'s (2011) quantitative study, which was based on multiple industry sectors in Germany. Blut et al. (2011) disaggregated the stages of the franchisee's lifecycle into four: (i) the honeymoon stage, i.e. the initial phase, (ii) the routine stage, i.e. the phase when franchisees are 
confronted with the realities of day-to-day business, (iii) the crossroad stage, i.e. the phase when franchisees gradually develop an understanding of the way the system works, and (iv) the stabilization stage, i.e. the maturity phase. Consistent with Paik and Choi (2007) and Dada et al.'s (2012) findings, Blut et al. (2011) found evidence of high franchisee autonomy at the stabilization stage, when franchisees would have acquired substantial experience. However, in general, Blut et al.'s (2011) findings revealed that franchisee autonomy will display a U-shaped curve that is high in the honeymoon and stabilization stages, but low in the routine and crossroad stages. Paik and Choi (2007), Blut et al. (2011) and Dada et al. (2012) were based on multiple theories, which may suggest complexities in studying the influence of age of the franchisee's firm on franchisee entrepreneurial autonomy. Nevertheless, reference to resource-based theory was common to all three studies, which may imply that franchisees' accumulated expertise overtime can lead to provision of increased informational capital, thereby enabling them to demand/enjoy more autonomy. Unlike the results reported earlier in relation to the negative influence of age of the franchisor's firm on franchisee entrepreneurial autonomy, the findings here demonstrate that franchisee autonomy varies across the stages of the franchisee's lifecycle.

In the quantitative and qualitative studies by Dant and Gundlach (1999), and Paik and Choi (2007), it was demonstrated that higher levels of success of the franchisee's business could lead to lower levels of franchisee autonomy. These results differ from those of the franchisor-drivers, which suggest that franchisor performance has a positive influence on franchisee entrepreneurial autonomy. The negative effect of franchisee's success on autonomy may arise because these franchisees are likely to attribute their success to the franchisor's efforts in successfully overcoming marketplace uncertainty and competition (Dant and Gundlach 1999). Successful franchisees may therefore value this rewarding franchisor role and may prefer the franchisor to be in control (Dant and Gundlach 1999). 
In terms of the personalities of individual franchisees, Weaven et al.'s (2010) qualitative study, conducted in Australia, indicate that franchisees who sought greater independence and autonomy through entering franchising were more likely to exercise entrepreneurial autonomy in their operations. This is because these franchisees are less likely to comply with system directives (Weaven et al. 2010). Since Weaven et al.'s (2010) study was based on conflict, the findings suggest that franchisees with a high desire for autonomy may not be appropriate for the franchise system, as they are more likely to strain the franchisor-franchisee relationship. These align with Dant et al.'s (2013b) study, which was based on role-theoretic B2B research; it was found that highly extraverted franchisees (who are linked with having high levels of entrepreneurial autonomy) will impede strong franchisor-franchisee relationship quality, and may have conflict with the franchisor. However, Huang and Phau's (2009) quantitative study, which was also conducted in Australia, demonstrate that franchisees with higher desire for autonomy are likely to be 'Best Buddy Franchisees' i.e. the model franchisees that are an asset to the franchise system. But it was found that franchisees with lower desire for autonomy are likely to be 'Black Sheep Franchisees' i.e. franchisees who are likely to act opportunistically. As Huang and Phau (2009) was based on agency theory, these findings may indicate that having franchisees with higher desire for autonomy can minimize agency costs. Overall, the results from Weaven et al. (2010) and Huang and Phau (2009) are not consistent in relation to whether it is better to have franchisees with high or low desires for autonomy. The findings seem to differ with regard to the methodological approaches and the theoretical perspectives adopted. Despite the disparities, the results still point to the same fact, i.e. the personalities of franchisees influence their entrepreneurial autonomy. These findings support those of Paswan and Cheng's (2013), based on role theory, which found that franchisees' perception of their roles (such as, when 
franchisees view themselves as owner-managers) influences the importance they associate with expectations of autonomy.

Prior studies have also explored the influence of franchisor characteristics, as desired by franchisees, on franchisee entrepreneurial autonomy. In a study by Altinay et al. (2013), it was found that when franchisees select franchisors that cannot meet the required task-related and partner-related criteria (used by franchisees to select their franchisor partners) it could result in franchisees' need or desire to work autonomously, acting more like independent entrepreneurs or mavericks, rather than conforming to the guidelines of the franchise system. These results are consistent with those of Dickey et al. (2007) and Davies et al. (2011) which suggest that franchisor trust (namely, franchisor overall trust, integrity trust and competence trust) negatively influences franchisee entrepreneurial autonomy. Reference to relationalbased theory was common to both of these studies, which may imply that complex issues that are not easily governed by a franchise contract (such as franchisee desire for autonomy) may be handled through norms of mutual trust (Dickey et al. 2007; Davies et al. 2011).

Furthermore, drawing mainly on learning perspective, Darr et al. (1995), Dada et al. (2012) and Melo et al. (2013) demonstrate the positive role of franchisee networks (e.g. franchisee forums, national forum and regional meetings) on franchisee entrepreneurial autonomy, such as for dissemination of new ideas and discussion of issues relating to entrepreneurship.

Only Perrigot et al. (2013) suggest that the use of the internet by franchisees for online selling has a positive impact on their entrepreneurial autonomy. Perrigot et al. (2013) demonstrate that when franchisees set up and run their own websites, their autonomy was reflected in the lack of uniformity in various dimensions relating to the (1) content and structure of the franchisees' websites and (2) the marketing-mix elements (i.e., products and services, prices, promotions, and place). 


\section{Internal moderators}

A few studies have explored factors that can moderate some of the relationships associated with franchisee entrepreneurial autonomy. Mumdžiev and Windsperger’s (2013) study, which was based on transaction cost theory, confirm the moderating role of trust by showing that trust increases allocation of decision rights [autonomy] to franchisees as it lessens opportunism risk and increases information sharing between the franchisor and the franchisees. First, Mumdžiev and Windsperger's (2013) findings suggest that trust can moderate the relationship between environmental uncertainty (an influencing factor) and franchisee entrepreneurial autonomy. This means that in a situation of high environmental uncertainty, franchisors will transfer more decision rights [autonomy] to franchisees if franchisees are perceived to be trustworthy (Mumdžiev and Windsperger 2013). Secondly, it was found that trust has a moderating effect on the relationship between behavioral uncertainty (an influencing factor) and the franchisor's propensity to delegate decision rights [autonomy] to franchisees. This means that in situations where franchisors find it difficult to measure franchisee performance, franchisors have less need to delegate decision rights to franchisees, as formal incentives, when they trust their franchisees (Mumdžiev and Windsperger 2013). Here, trust reduces the positive effect of behavioral uncertainty on franchisee autonomy.

Furthermore, only Cochet et al. (2008) revealed that franchisee incentive characteristics- namely, franchisee success, multi-unit ownership and intra-chain competition- will moderate the relationship between relational governance (a control mechanism) and franchisee autonomy. More specifically, franchisee success and multi-unit ownership will reduce the need for the franchisor's use of relational governance, and intrachain competition will increase the need for the franchisor's use of relational governance 
(Cochet et al. 2008). This is because there may be less misuse of autonomy amongst the more successful franchisees and multi-unit franchisees, whilst there may be more misuse of autonomy amongst franchisees who perceive higher levels of intra-chain competition. The findings, which were based on agency theory, suggest that the importance of relational governance as a control mechanism for franchisee autonomy varies across different franchisee incentive characteristics.

Phan et al. (1996) and Grünhagen et al. (2014) demonstrate the moderating roles of franchisor-suasion tactics and HR operational autonomy, respectively, in the relationship between franchisee entrepreneurial autonomy and franchisor performance. Based on agency and strategic theoretical perspectives, Phan et al. (1996) found that franchisor-suasion tactics (i.e. the franchisor's attempts to influence franchisees by means of franchisor's strategy advice) will strengthen the relationship between entrepreneur-franchisee strategy [i.e. franchisee entrepreneurial autonomy] and franchisee performance, resulting in higher levels of franchisee sales. This finding implies positive outcomes for the franchisor; unlike franchisees who have profit-maximization goals, franchisors have sales maximization goals because payment of royalties is based on sales (Phan et al. 1996). Based on a sample of franchisors in the UK, and drawing on property rights theory, the quantitative study by Grünhagen et al. (2014) indicates that when franchisees are given greater autonomy in HR policies, their entrepreneurial orientation (i.e. innovativeness, proactiveness and risk-taking) will have a stronger positive impact on franchise system performance.

Furthermore, findings from Phan et al. (1996) demonstrate that two factors- notably, franchise contract formal goals and franchisor-suasion tactics- may strengthen the negative relationship between franchisee entrepreneurial autonomy and franchisee performance. Both factors were found to moderate the relationship between entrepreneur-franchisee strategy and franchisee performance, resulting in lower profits for franchisees. 


\section{Internal mediator}

Only a single study was found to have explored a factor that can mediate relationships associated with franchisee entrepreneurial autonomy. Drawing on learning perspective, findings from Darr et al. (1995) suggest that transfer of learning is a mediator in the relationship between franchisee entrepreneurial autonomy and resulting positive outcomes. It was found that a franchisee's outlet-level innovation leads to extensive transfer of learning between franchisees and franchisors, which in turn leads to system-wide adaptations (of the innovation), and/or adaptations to the other outlets owned by the franchisee who originated the innovation (Darr et al. 1995).

\section{Discussion}

Since the franchisor has profound interest in enforcing franchisee compliance to operational standards and corporate rules, there are many ambiguities surrounding the notion of franchisee autonomy (Dant and Gundlach 1999; Davies et al. 2011). This review has generated a model that aids better understanding of these issues. The model identifies why franchisee entrepreneurial autonomy might/might not occur in relation to its drivers, how it can be relevant/irrelevant in terms of its consequences, how it can be managed by franchisors and their franchisees in terms of controls, and what types of factors can strengthen/weaken or intervene relationships in the model.

\section{Research implications}

Irrespective of the countries studied, franchisee entrepreneurial autonomy provides positive outcomes. Most studies reporting positive outcomes were conducted in the US. Others were undertaken in the UK, Australasia, Canada, Israel, Germany and Brazil. Agency and 
resource-based theories were mostly referenced in studies capturing the positive outcomes of franchisee entrepreneurial autonomy. These suggest how agents (franchisees), through their autonomy, contribute entrepreneurial resources to the franchise organization. However, relational exchange-based theory provided supplementary insights beyond agency and resource contributions of franchisees. More specifically, relational exchange-based theory provided knowledge on the dynamics of franchisor-franchisee relations that arise as a result of franchisee autonomy.

Only studies conducted in the US and Australia reported negative outcomes. These two countries have mature franchising sectors (Dant 2008; Frazer et al. 2012), which suggest that they may have more well established franchise systems. Hence, it is possible that the negative outcomes in the US and Australia occur because franchisee entrepreneurial autonomy may be associated with franchisee deviating from the tried and tested systems in these more established organizations. Indeed, Frazer et al. (2012) noted that most of the substantial disputes reported by franchisors occur in larger and older systems, and a main cause of dispute include issues related to compliance with the system. Agency theory was mostly referenced in studies capturing the negative outcomes, which suggests that this theoretical perspective indicates the increased agency costs associated with franchisee entrepreneurial autonomy.

By drawing on agency theoretic arguments, it is widely believed that contracts are used for controlling franchisee behavior. This review, however, revealed wider mechanisms for managing entrepreneurial autonomy in franchised outlets. Findings from studies based on agency theory, for example, show that franchisors use alternative mechanisms for this purpose (e.g. Clarkin and Rosa 2005; Cochet et al. 2008). These imply that franchisors can minimize agency costs that may be associated with franchisee entrepreneurial autonomy by using a diverse range of mechanisms beyond the contractual agreement. 
Furthermore, franchisors exercise control mechanisms that reflect their unilateral dominance in monitoring franchisees, such that franchisee entrepreneurial autonomy has to be in accordance with the franchisor's guidelines and/or have the franchisor's approval. In contrast, franchisees exercise control mechanisms designed around maintaining a unified franchisee network. The evidence shows that social control mechanisms exercised by franchisees can complement the formal and contractually-based controls commonly examined in the literature (Akremi et al. 2011), which mostly draw on agency theory. Franchisors could use formal controls together with social controls because the strict formal controls tend to sour relations with franchisees (Akremi et al. 2011).

This review further identified a range of external and internal drivers of franchisee entrepreneurial autonomy, which imply that there is a need for franchisee entrepreneurial autonomy under certain conditions and in different franchising contexts (e.g. Bradach 1997; Mumdžiev and Windsperger 2013). In terms of the external influencing factors, agency theory and resource-based theory were mostly applied, and were complementary in showing how agents' (franchisees') conversance with their industry and local market opportunities enable introduction of new knowledge (entrepreneurial resources) to franchise systems. In relation to the internal influencing factors from the franchisor's perspective, the following six theoretical perspectives were mostly applied: agency theory, resource-based theory, organizational identity theory, exchange theory, property rights theory and transaction cost theory. Collectively, these theories imply that some franchisors may realize that the performance, development and growth of their systems can be influenced positively via franchisee entrepreneurial autonomy. In terms of studying the internal influencing factors from the franchisee's perspective, the following six theoretical perspectives were mostly referenced: resource-based theory, agency theory, relational-based theory, learning perspective, role-based theory and channel theory. Together, these theories show how 
franchisees' accrued experience, knowledge and personal profile affect their levels of entrepreneurial autonomy.

This review further shows that the following four theories are appropriate for understanding the internal moderators associated with franchisee entrepreneurial autonomy: agency theory and strategic perspective (captures the moderating effect of franchisee incentive characteristics, franchise contract formal goals, and franchisor's attempts to influence franchisees by means of franchisor's strategy advice); transaction cost theory (captures the moderating effect of trust); and property rights theory (captures the moderating effect of HR operational autonomy).

Only learning perspective was found to have been applied for understanding the internal mediator associated with franchisee entrepreneurial autonomy. This perspective captures the transfer of learning that intervenes the relationship between franchisee entrepreneurial autonomy and the associated positive outcomes.

Table 2 summarizes the strengths of agency theory, resource-based theory and the other mostly used theoretical perspectives discussed above, in relation to the core factors associated with franchisee entrepreneurial autonomy. Although diverse theoretical perspectives were found to be informative in this review, agency theory appears to be the best approach for capturing the various phenomena in the model of franchisee entrepreneurial autonomy. Agency theory was consistently effective in providing knowledge on each of the individual dimensions of the model, with the exception of only one dimension (internal mediator). This might explain why it has been widely used in prior studies of franchisee entrepreneurial autonomy.

\section{INSERT TABLE 2 ABOUT HERE}




\section{Practitioner implications}

By establishing autonomy, managers demonstrate to organizational members that they have confidence in their ability to perform effectively outside the rubric of firm boundaries (Hughes and Morgan 2007). The present review identifies factors that franchisors can employ to boost their understanding of, and confidence in, franchisee entrepreneurial autonomy. Franchisors interested in encouraging franchisee entrepreneurial autonomy can utilize the results to identify influencing factors that can provide directions for both franchise partners. The control mechanisms identified in the model can be used by franchisors to have a clearer understanding of how autonomy can be sustained without damaging the standardization on which franchising is designed. The control mechanisms can also help franchisees to understand how they can manage their entrepreneurial autonomy to fit the franchisor's requirements. The effectiveness of the control mechanisms was noted in four of the studies in this review. Where franchisees exercised autonomy by using control mechanisms as a guide, the mechanisms reduced the need for the franchisor's involvement in terms of control (Bradach 1997). The control mechanisms also promote supportive and cooperative franchisors (Clarkin and Rosa 2005; Dada et al. 2012) and maintain standardization amongst franchisees (Akremi et al. 2011; Dada et al. 2012; Melo et al. 2013). The model suggests that franchise organizations that foster franchisee entrepreneurial autonomy may differ from those that do not, in terms of the organizational outcomes. These results set a context for practitioners to appreciate the value of franchisee entrepreneurial autonomy, while exercising caution to prevent negative outcomes.

\section{Limitations and directions for future research}

Despite the contributions of this study, it has potential limitations that provide opportunities for future research (Michael and Combs 2008). First, although this study was based on a 
systematic review, it is impossible to guarantee an absence of publication bias (Nijmeijer et al. 2014). However, in searching and selecting the articles to be included in this review, various strategies were employed (as outlined in the methodology section) to minimize bias in the final sample utilized for this study. Second, the results indicate that some theoretical perspectives were utilized more than others; these might have limited the inferences derived from this review. Third, as the present study excluded articles that were solely focused on international franchising, this might limit the relevance of the findings for franchisors that operate in international markets.

In terms of future research, studies that will examine the optimal levels of franchisee entrepreneurial autonomy are required to aid understanding of this research area. For example, research can explore which of the different influencing factors provide optimal levels of franchisee entrepreneurial autonomy. It is worth comparing the optimal levels of franchisee entrepreneurial autonomy in different countries. Additionally, researchers can explore more about the underlying dynamics behind the negative outcomes reported in the US and Australia. It would be interesting to see reviews on franchisee entrepreneurial autonomy within the context of international franchising. Exploring how these differ from a domestic market context, and the factors that drive these differences, may enable understanding of the level of leeway to be provided to franchisees depending on their geographical locations.

Some of the core factors in the model- notably, the moderating and mediating factors- have received less research attention. Studies focusing on these under-researched areas might advance our knowledge of franchisee entrepreneurial autonomy. Additionally, despite evidence showing the use of a wide range of control mechanisms, little is known about their efficacy. Comparative studies can be designed to examine the value of the control mechanisms, e.g., whether the control mechanisms exercised by franchisors are more/less 
effective than those exercised by franchisees, and whether formal control mechanisms are more/less effective than social control mechanisms. Furthermore, most of the studies employed quantitative research designs, more qualitative studies are required to examine the intricacies of entrepreneurial autonomy in franchising.

Although a wide range of theories was adopted in prior studies, some perspectives remain dominant (i.e. agency and resource-based theories). The less applied theories (e.g. stewardship theory, tournament theory, U-curve theory and institutional theory) can provide directions for future research. Scholars can draw together agency and stewardship theories, in a complementary framework, to examine how the franchisor's role as principal affects the level of autonomy granted to franchisees when the latter are viewed as stewards. Stewardship theory (Davis et al. 1997) suggests that if franchisees are motivated as stewards, they will act pro-organizationally, such that the granting of greater autonomy to franchisees should have positive impact on the franchisor-franchisee relationship (Dada and Watson 2012). This is because the franchisee's behavior will not depart from the interests of his or her franchisor (see Davis et al. 1997; Dada and Watson 2012). Stewardship theory therefore addresses a weakness of agency theory, where the latter views franchisees as agents who may have agency costs (such as free-riding and negative opportunistic behaviors) in situations where they exercise autonomy (Dada and Watson 2012).

Tournament theory and U-curve theory (see Blut et al. 2011; Gillis et al. 2011) can be combined to examine if franchisors use franchisee entrepreneurial autonomy as a type of tournament (i.e. incentive) at different stages of the franchisee's business lifecycle. As Gillis et al. (2011) explained, the premise of a tournament is to only reward agents who produce the highest levels of output. The authors argued that franchisors in some systems set up a tournament among their franchisees where franchisors identify those franchisees that are capable of contributing back to the franchise system through knowledge-sharing routines 
(e.g. identifying and developing good ideas). Franchisors then reward the identified franchisees for their contributions by giving them additional outlets, thereby transforming single outlet franchisees to multiple outlet franchisees, and increasing their wealth in the process (Gillis et al. 2011). As the authors argued, this reward acts as an important incentive for franchisees to act in the franchisor's interests. It will also be interesting for future studies to examine outcomes of franchisee autonomy if the latter is used as a tournament across the franchisee’s business lifecycle.

Institutional theory suggests that "it is possible to predict practices within organizations from perceptions of legitimate behavior derived from cultural values, industry tradition, firm history, popular management folklore, and the like” (Eisenhardt 1988: 492). Scholars can draw on institutional theory to explore potential institutional influences that affect the level of autonomy granted to franchisees. Studies using examples of these less explored theories can advance understanding of franchisee entrepreneurial autonomy. Indeed, researchers have called for greater theoretical diversity in franchise research (see Combs et al. 2009; Combs et al. 2011).

\section{Conclusion}

This paper contributes to knowledge by developing a broad model of core factors and associated secondary factors that are important for understanding franchisee entrepreneurial autonomy. The evidence highlights the superiority of agency theory in effectively studying most of the phenomena in the model, notably a range of influences, controls, outcomes, and moderating factors that contribute to the understanding of franchisee entrepreneurial autonomy. Although franchisee entrepreneurial autonomy may conflict with the 
standardization required in franchise systems, the findings from the review suggest that franchisors foresee autonomy to occur at some point and they draw on a broad range of mechanisms to manage this expectancy. Contrary to what might be expected, this review further adds to the literature by showing that it is not just the franchisor that can control entrepreneurial autonomy in franchised outlets, but also the franchisee. Unlike the franchisor control mechanisms which reflect the franchisor's authority, franchisee control mechanisms centre largely on maintaining social procedures and relationships. The findings suggest that the simultaneous use of control mechanisms with franchisee entrepreneurial autonomy may minimize negative outcomes.

\section{References}

Altinay, L., Brookes, M. and Aktas, G. (2013). Selecting franchise partners: Tourism franchisee approaches, processes and criteria. Tourism Management, 37, pp. 176-185.

Akremi, A., Mignonac, K. and Perrigot, R. (2011). Opportunistic behaviors in franchise chains: The role of cohesion among franchisees. Strategic Management Journal, 32, pp. 930-948.

Barthélemy, J. (2008). Opportunism, knowledge, and the performance of franchise chains. Strategic Management Journal, 29, pp. 1451-1463.

Barthélemy, J. (2011). Agency and institutional influences on franchising decisions. Journal of Business Venturing, 26(1), pp. 93-103.

Berg, B.L. (2001). Qualitative research methods for the social sciences. Allyn \& Bacon. Accessed online on 14 May 2013. http://mthoyibi.files.wordpress.com/2011/05/qualitative-research-methods-for-thesocial-sciences__bruce-l-berg-2001.pdf

Berkowitz, D. and Wren, B.M. (2013). Creating strategic commitment in franchise systems: Establishing the link between leadership, organizational structure, and performance. Journal of Small Business and Entrepreneurship, 26(5), pp. 481-492.

Birkeland, P.M. (2002). Franchising dreams: The lure of entrepreneurship in America. Chicago and London: The University of Chicago Press. 
Blut, M., Backhaus, C., Heussler, T., Woisetschläger, D.M., Evanschitzky, H. and Ahlert, D. (2011). What to expect after the honeymoon: Testing a lifecycle theory of franchise relationships. Journal of Retailing, 87(3), pp. 306-319.

Bradach, J.L. (1997). Using the plural form in the management of restaurant chains. Administrative Science Quarterly, 42, pp. 276-303.

Caza, A. (2012). Typology of the eight domains of discretion in organizations. Journal of Management Studies, 49(1), pp. 144-177.

Cetindamar, D., Wasti, S.N., Ansal, H. and Beyhan, B. (2009). Does technology management research diverge or converge in developing and developed countries? Technovation, 29(1), pp. 45-58.

Clarkin, J.E. and Rosa, P.J. (2005). Entrepreneurial teams within franchise firms. International Small Business Journal, 23(3), pp. 303-334.

Cochet, O. and Garg, V.K. (2008). How do franchise contracts evolve? A study of three German SMEs. Journal of Small Business Management, 46(1), pp. 134-151.

Cochet, O., Dormann, J. and Ehrmann, T. (2008). Capitalizing on franchisee autonomy: Relational forms of governance as controls in idiosyncratic franchise dyads. Journal of Small Business Management, 46(1), pp. 50-72.

Combs, J.G., and Ketchen, D.J. (1999). Can capital scarcity help agency theory explain franchising? Revisiting the capital scarcity hypothesis. Academy of Management Journal, 42(2), pp. 196-207.

Combs, J.G. and Ketchen, D.J. (2003). Why do firms use franchising as an entrepreneurial strategy? A meta-analysis. Journal of Management, 29(3), pp. 443-465.

Combs, J.G., Ketchen, D.J. and Hoover, V.L. (2004a). A strategic groups approach to the franchising-performance relationship. Journal of Business Venturing, 19, pp. 877897.

Combs, J.G., Michael, S.C. and Castrogiovanni, G. (2004b). Franchising: A review and avenues to greater theoretical diversity. Journal of Management, 30, pp. 907-931.

Combs, J.G., Michael, S.C. and Castrogiovanni, G.J. (2009). Institutional influences on the choice of organizational form: The case of franchising. Journal of Management, 35(5), pp. 1268-1290.

Combs, J.G., Ketchen, D.J., Shook, C.L. and Short, J.C. (2011). Antecedents and consequences of franchising: Past accomplishments and future challenges. Journal of Management, 37(1), pp. 99-126.

Cook, D.J., Mulrow, C.D. and Haynes, R.B. (1997). Systematic reviews: Synthesis of best evidence for clinical decisions. Annals of Internal Medicine, 126, pp. 376-380.

Cox, J. and Mason, C. (2007). Standardization versus adaptation: Geographical pressures to 
deviate from franchise formats. Service Industries Journal, 27(8), pp. 1053-1072.

Cox, J. and Mason, C. (2009). Franchise network restructuring: Pressures, constraints and mechanisms. Entrepreneurship and Regional Development, 21(5-6), pp. 503-527.

Cummings, G.G., MacGregor, T., Davey, M., Lee, H., Wong, C.A., Lo, E., Muise, M. and Stafford, E. (2010). Leadership styles and outcome patterns for the nursing workforce and work environment: A systematic review. International Journal of Nursing Studies, 47, pp. 363-385.

Dada, O. and Watson, A. (2012). The effect of entrepreneurial orientation on the franchise relationship. International Small Business Journal, 31(8), 955-977.

Dada, O., Watson, A. and Kirby, D. (2012). Toward a model of franchisee entrepreneurship. International Small Business Journal, 30(5), pp. 559-583.

Dada, O. and Watson, A. (2013). Entrepreneurial orientation and the franchise system: Organizational antecedents and performance outcomes. European Journal of Marketing, 47(5/6), pp. 790-812.

Dant, R.P. and Gundlach, G.T. (1999). The challenge of autonomy and dependence in franchised channels of distribution. Journal of Business Venturing, 14, pp. 35-67.

Dant, R.P. (2008). A futuristic research agenda for the field of franchising. Journal of Small Business Management, 46, pp. 91-98.

Dant, R.P., Weaven, S.K., Baker, B.L. and Jeon, H.J. (2013a) An introspective examination of single-unit versus multi-unit franchisees. Journal of the Academy of Marketing Science, 41, pp. 473-496.

Dant, R.P., Weaven, S.K. and Baker, B.L. (2013b) Influence of personality traits on perceived relationship quality within a franchisee-franchisor context. European Journal of Marketing, 47(1/2), pp. 279-302.

Darr, E.D., Argote, L. and Epple, D. (1995). The acquisition, transfer, and depreciation of knowledge in service organizations: Productivity in franchises. Management Science, 41(11), pp. 1750-1762.

Davey, M.M., Cummings, G., Newburn-Cook, C.V. and Lo, E.A. (2009). Predictors of nurse absenteeism in hospitals: A systematic review. Journal of Nursing Management, 17, pp. 312-330.

Davies, M.A.P, Lassar, W., Manolis, C., Prince, M. and Winsor, R.D. (2011). A model of trust and compliance in franchise relationships. Journal of Business Venturing, 26(3), pp. 321-340.

Davis, J.H., Schoorman, D. and Donaldson, L. (1997). Toward a stewardship theory of management. Academy of Management Review, 22(1), pp. 20-47.

de Azevedo, P.F. (2009). Allocation of authority in franchise chains. International Studies of 
Management and Organization, 39(4), pp. 31-42.

de Menezes, L.M. and Kelliher, C. (2011). Flexible working and performance: A systematic review of the evidence for a business case. International Journal of Management Reviews, 13, pp. 452-474.

Dess, G.G., Ireland, R.D., Zahra, S.A., Floyd, S.W., Janney, J.J. and Lane, P.J. (2003) Emerging issues in corporate entrepreneurship. Journal of Management, 29, pp. 351378.

Denyer, D. and Neely, A. (2004). Introduction to special issue: Innovation and productivity performance in the UK. International Journal of Management Reviews, 5, pp. 131135.

Dickey, M.H. and Ives, B. (2000). The impact of intranet technology on power in franchisee/franchisor relationships. Information Systems Frontiers, 2(1), pp. 99-114.

Dickey, M.H., McKnight, D.H. and George, J.F. (2007). The role of trust in franchise organizations. International Journal of Organizational Analysis, 15(3), pp. 251-282.

DiPietro, R.B., Welsh, D.H.B., Raven, P.V. and Severt, D. (2007). A measure of hope in franchise systems: Assessing franchisees, top executives, and franchisors. Journal of Leadership and Organizational Studies, 13(3), pp. 59-66.

Doherty, A.M. and Quinn, B. (1999). International retail franchising: An agency theory perspective. International Journal of Retail and Distribution Management, 27(6), pp. 224-237.

Eisenhardt, K.M. (1988). Agency- and institutional-theory explanations: The case of retail sales compensation. Academy of Management Journal, 31(3), pp. 488-511.

Engström, J., Bruno, E., Holm, B. and Hellzén, O. (2007). Palliative sedation at end of life: A systematic literature review. European Journal of Oncology Nursing, 11, pp. 26-35.

European Franchise Federation (2010) http://www.eff-franchise.com/spip.php?rubrique. Accessed on 22 ${ }^{\text {nd }}$ August 2013.

Evanschitzky, H., Caemmerer, B. and Backhaus, C. (2016). The franchise dilemma: Entrepreneurial characteristics, relational contracting, and opportunism in hybrid governance. Journal of Small Business Management, 54(1), pp. 279-298.

Falbe, C.M., Dandridge, T.C. and Kumar, A. (1998). The effect of organizational context on entrepreneurial strategies in franchising. Journal of Business Venturing, 14(1), pp. 125-40.

Flint-Hartle, S. and de Bruin, A. (2011). Franchising success: Insights from real estate brokerage. International Small Business Journal, 29(1), pp. 58-77.

Frazer, L., Weaven, S., Giddings, J. and Grace, D. (2012) What went wrong? Franchisors 
and franchisees disclose the causes of conflict in franchising. Qualitative Market Research: An International Journal, 15(1), pp. 87-103.

Gassenheimer, J.B., Baucus, D.B. and Baucus, M.S. (1996). Cooperative arrangements among entrepreneurs: An analysis of opportunism and communication in franchise structures. Journal of Business Research, 36(1), pp. 67-79.

Germain, P.B. and Cummings, G.G. (2010). The influence of nursing leadership on nurse performance: A systematic literature review. Journal of Nursing Management, 18(4), pp. 425-439.

Gillis, W.E., McEwan, E., Crook, T.R. and Michael, S.C. (2011). Using tournaments to reduce agency problems: The case of franchising. Entrepreneurship Theory and Practice, May, pp. 427-447.

Gorovaia, N. and Windsperger, J. (2013). Real options, intangible resources and performance of franchise networks. Managerial Decision Economics, 34, pp. 183194.

Grünhagen, M. and Mittelstaedt, R.A. (2005). Entrepreneurs or investors: Do multi-unit franchisees have different philosophical orientations? Journal of Small Business Management, 43(3), pp. 207-225.

Grünhagen, M., Wollan, M.L., Dada, L. and Watson, A. (2014). The moderating influence of HR operational autonomy on the entrepreneurial orientation-performance link in franchise systems. International Entrepreneurship and Management Journal, 10(4), 827-844.

Heeks, R. and Bailur, S. (2007). Analyzing e-government research: Perspectives, philosophies, theories, methods, and practice. Government Information Quarterly, 24(2), pp. 243-265.

Hing, N. (1995). Franchisee satisfaction: Contributors and consequences. Journal of Small Business Management, 33(2), pp. 12-25.

Hoy, F. and Shane, S. (1998). Franchising as an entrepreneurial venture form. Journal of Business Venturing, 13(2), pp. 91-94.

Hoy, F. (2008). Organizational learning at the marketing/entrepreneurship interface. Journal of Small Business Management, 46(1), pp. 152-158.

Huang, Y. and Phau, I. (2009). Mapping the profiles of franchisees: Getting to know the black sheep, rough diamonds, whingers and best buddies. Direct Marketing: An International Journal, 2(4), pp. 221-238.

Hughes, M. and Morgan, R. (2007). Deconstructing the relationship between entrepreneurial orientation and business performance at the embryonic stage of firm growth. Industrial Marketing Management, 36(5), pp. 651-661.

Hussain, D. and Windsperger, J. (2011). Multi-unit franchising: A Comparative case analysis. 
Journal of Applied Business Research, 27(1), pp. 103-111.

Jambulingam, T. and Nevin, J.R. (1999). Influence of franchisee selection criteria on outcomes desired by the franchisor. Journal of Business Venturing, 14(4), pp. 363395.

Kaufmann, P.J. (1999). Franchising and the choice of self employment. Journal of Business Venturing, 14, pp. 345-362.

Kaufmann, P.J. and Dant, R.P. (1998). Franchising and the domain of entrepreneurship research. Journal of Business Venturing, 14, pp. 5-16.

Kaufmann, P.J. and Eroglu, S. (1998). Standardization and adaptation in business format franchising. Journal of Business Venturing, 14, pp. 69-85.

Ketchen, D.J., Short, J.C. and Combs, J.G. (2011). Is franchising entrepreneurship? Yes, no, and maybe so. Entrepreneurship Theory and Practice, May, pp. 583-593.

Keupp, M.M., Palmié, M. and Gassmann, O. (2012). The strategic management of innovation: A systematic review and paths for future research. International Journal of Management Reviews, 14, pp. 367-390.

Kidwell, R.E., Nygaard, A. and Silkoset, R. (2007). Antecedents and effects of free riding in the franchisor-franchisee relationship. Journal of Business Venturing, 22, pp. 522544.

Langfred, C.W. (2004). Too much of a good thing? Negative effects of high trust and individual autonomy in self-managing teams. Academy of Management Journal, 47(3), pp. 385-399.

Langfred, C.W. (2005). Autonomy and performance in teams: The multilevel moderating effect of task interdependence. Journal of Management, 31(4), pp. 513-529.

López-Bayón, S. and López-Fernández, B. (2016). Partner empowerment and relationship failure in franchising. Journal of Small Business Management, Forthcoming.

Lumpkin, G.T. and Dess, G. (1996). Clarifying the entrepreneurial orientation construct and linking it to performance. Academy of Management Review, 21(1), pp. 135-172.

Lumpkin, G.T., Cogliser, C.C. and Schneider, D.R. (2009). Understanding and measuring autonomy: An entrepreneurial orientation perspective. Entrepreneurship Theory and Practice, January, pp. 47-69.

Maritz, A. (2006). A cross-tasman perspective of entrepreneurial orientation of franchisees. Applied Research Journal, 5(1), pp. 1-10.

Mays, N., Pope, C. and Popay, J. (2005). Systematically reviewing qualitative and quantitative evidence to inform management and policy-making in the health field. Journal of Health Services Research and Policy, 10, pp. 6-20. 
Meek, W.R., Davis-Sramek, B., Baucus, M.S. and Germain, R.N. (2011). Commitment in franchising: The role of collaborative communication and a franchisee's propensity to leave. Entrepreneurship Theory and Practice, 35(3), pp. 559-581.

Melo, P.L., Andreassi, T., Junior, M. and Borini, F.M. (2013). Influence of the operating environment on organization innovation: A multiple case study of food franchises in Brazil. International Journal of Management, 30(2), pp. 402-420.

Michael, S.C. and Combs, J.G. (2008). Entrepreneurial failure: The case of franchisees. Journal of Small Business Management, 46(1), pp. 73-90.

Mo, P.K.H., Malik, S.H. and Coulson, N.S. (2009). Gender differences in computer-mediated communication: A systematic literature review of online health-related support groups. Patient Education and Counseling, 75, pp. 16-24.

Mumdžiev, N. and Windsperger, J. (2011). The structure of decision rights in franchising networks: A property rights perspective. Entrepreneurship Theory and Practice, May, pp. 449-465.

Mumdžiev, N. and Windsperger, J. (2013). An extended transaction cost model of decision rights allocation in franchising: The moderating role of trust. Managerial and Decision Economics, 34, pp. 170-182.

Neuendorf, K.A. (2002). The content analysis guidebook. Sage.

Nijmeijer, K.J., Fabbricotti, I.N. and Huijsman, R. (2014). Making franchising work: A framework based on a systematic review. International Journal of Management Reviews, 16(1), pp. 62-83.

Paik, Y. and Choi, D.Y. (2007). Control, autonomy and collaboration in the fast food industry: A comparative study between domestic and international franchising. International Small Business Journal, 25(5), pp. 539-562.

Paswan, A. and Cheng, J.M.S. (2013). Franchisee role perceptions and expectations: A study in Taiwanese franchise industry. Journal of Marketing Channels, 20(1-2), pp. 169-184.

Perrigot, R., Basset, G., Briand, D., and Cliquet, G. (2013). Uniformity in franchising: A case study of a French franchise network with several franchisees having their own website. Journal of Marketing Channels, 20(1-2), pp. 99-119.

Phan, P.H., Butler, J.E. and Lee, S.H. (1996). Crossing mother: Entrepreneur- franchisees' attempts to reduce franchisor influence. Journal of Business Venturing, 11(5), pp. 379-402.

Pittaway, L., Robertson, M., Munir, K., Denyer, D. and Neely, A. (2004). Networking and innovation: A systematic review of the evidence. International Journal of Management Reviews, 5, pp. 137-168.

Pizanti, I. and Lerner, M. (2003). Examining control and autonomy in the franchisor- 
franchisee relationship. International Small Business Journal, 21, pp. 131-159.

Prasad, B.D. (2008). Content analysis: A method in social science research. From: Lal Das, D.K. and Bhaskaran, V. (eds.) Research methods for Social Work, New Delhi: Rawat, pp.173-193. Assessed online on 14 May 2013. http://www.css.ac.in/download/deviprasad/content\%20analysis.\%20a\%20method\%20 of\%20social\%20science\%20research.pdf

Shane, S.A. and Hoy, F. (1996). Franchising: A gateway to cooperative entrepreneurship. Journal of Business Venturing, 11, pp. 325-327.

Silverman, D. (2013). Doing qualitative research. Fourth Edition, Sage.

Sirola-Karvinen, P. and Hyrkäs, K. (2006). Clinical supervision for nurses in administrative and leadership positions: A systematic literature review of the studies focusing on administrative clinical supervision. Journal of Nursing Management, 14, pp. 601-609.

Sorenson, O. and Sørensen, J.B. (2001). Finding the right mix: Franchising, organizational learning, and chain performance. Strategic Management Journal, 22, pp. 713-724.

Stemler, S. (2001). An overview of content analysis. Practical Assessment, Research and Evaluation 7(17). Accessed online on 10 May 2013 http://pareonline.net/getvn.asp?v=7\&n=17

Strutton, D., Pelton, L.E. and Lumpkin, J.R. (1995). Psychological climate in franchising system channels and franchisor-franchisee solidarity. Journal of Business Research, 34, pp. 81-91.

Thorpe, R., Holt, R., Macpherson, A. and Pittaway, L. (2005). Using knowledge within small and medium-sized firms: A systematic review of the evidence. International Journal of Management Reviews, 7, pp. 257-281.

Tranfield, D., Denyer, D. and Smart, P. (2003). Towards a methodology for developing evidence-informed management knowledge by means of systematic review. British Journal of Management, 14, pp. 207-222.

Wales, W.J., Gupta, V.K. and Mousa, F-T. (2013). Empirical research on entrepreneurial orientation: An assessment and suggestions for future research. International Small Business Journal, 31(4), pp. 357-383.

Wang, C.L. and Chugh, H. (2014). Entrepreneurial learning: Past research and future challenges. International Journal of Management Reviews, 16(1), pp.24-61.

Watson, A., Dada, O., Grünhagen, M. and Wollan, M.L. (2016) When do franchisors select entrepreneurial franchisees? An organizational identity perspective. Journal of Business Research. Forthcoming.

Weaven, S. and Frazer, L. (2007). Expansion through multiple unit franchising: Australian franchisors reveal their motivations. International Small Business Journal, 25(2), pp. 173-205. 
Weaven, S. and Herington, C. (2007). Factors influencing governance choice and human resource management within services franchising networks. Journal of Management and Organization, 13, pp. 126-144.

Weaven, S., Grace, D. and Manning, M. (2009). Franchisee personality: An examination in the context of franchise unit density and service classification. European Journal of Marketing, 43(1/2), pp. 90-109.

Weaven, S., Frazer, L. and Giddings, J. (2010). New perspectives on the causes of franchising conflict in Australia. Asia Pacific Journal of Marketing and Logistics, 22(2), pp. 135-155.

Whetten, D.A. (1989). What constitutes a theoretical contribution? Academy of Management Review, 14(4), pp. 490-495.

Winter, S.G., Szulanski, G., Ringov, D. and Jensen, R.J. (2012). Reproducing knowledge: Inaccurate replication and failure in franchise organizations. Organization Science, 23(3), pp. 672-685.

Yin, X. and Zajac, E.J. (2004). The strategy/governance structure fit relationship: Theory and evidence in franchising arrangements. Strategic Management Journal, 25, pp. 365-383.

Zachary, M.A., McKenny, A.F., Short, J.C., Davis, K.M. and Wu, D. (2011). Franchise branding: An organizational identity perspective. Journal of the Academy of Marketing Science, 39, pp. 629-645.

Zerbinati, S. and Souitaris, V. (2005). Entrepreneurship in the public sector: A framework of analysis in European local governments. Entrepreneurship and Regional Development, 17, pp. 43-64.

\section{Appendix}

INSERT TABLE 1 in the Appendix 
Table 2. Strengths of the mostly used theoretical perspectives, in relation to the core factors associated with franchisee entrepreneurial autonomy

\begin{tabular}{|c|c|}
\hline Theoretical perspectives & Strengths \\
\hline Agency theory & $\begin{array}{l}\text { Captures the positive and negative outcomes of franchisee entrepreneurial autonomy } \\
\text { Aids understanding of the mechanisms for controlling franchisee entrepreneurial autonomy } \\
\text { Provides knowledge on the external factors that influence franchisee entrepreneurial autonomy } \\
\text { Effective for studying the internal influencing factors of franchisee entrepreneurial autonomy from the franchisor's perspective } \\
\text { Appropriate for studying the internal influencing factors of franchisee entrepreneurial autonomy from the franchisee's perspective } \\
\text { Aids understanding of the internal moderators associated with franchisee entrepreneurial autonomy }\end{array}$ \\
\hline Resource-based theory & $\begin{array}{l}\text { Captures the positive outcomes of franchisee entrepreneurial autonomy } \\
\text { Provides knowledge on the external factors that influence franchisee entrepreneurial autonomy } \\
\text { Effective for studying the internal influencing factors of franchisee entrepreneurial autonomy from the franchisor's perspective } \\
\text { Appropriate for studying the internal influencing factors of franchisee entrepreneurial autonomy from the franchisee's perspective }\end{array}$ \\
\hline $\begin{array}{l}\text { Relational exchange-based } \\
\text { theory }\end{array}$ & $\begin{array}{l}\text { Provides knowledge on the dynamics of franchisor-franchisee relations that arise as a result of franchisee autonomy } \\
\text { Effective for studying the internal influencing factors of franchisee entrepreneurial autonomy from the franchisor's perspective } \\
\text { Appropriate for studying the internal influencing factors of franchisee entrepreneurial autonomy from the franchisee's perspective }\end{array}$ \\
\hline $\begin{array}{l}\text { Organizational identity } \\
\text { theory }\end{array}$ & Effective for studying the internal influencing factors of franchisee entrepreneurial autonomy from the franchisor's perspective \\
\hline Property rights theory & $\begin{array}{l}\text { Effective for studying the internal influencing factors of franchisee entrepreneurial autonomy from the franchisor’s perspective } \\
\text { Aids understanding of the internal moderators associated with franchisee entrepreneurial autonomy }\end{array}$ \\
\hline Transaction cost theory & $\begin{array}{l}\text { Effective for studying the internal influencing factors of franchisee entrepreneurial autonomy from the franchisor’s perspective } \\
\text { Aids understanding of the internal moderators associated with franchisee entrepreneurial autonomy }\end{array}$ \\
\hline Learning perspective & $\begin{array}{l}\text { Appropriate for studying the internal influencing factors of franchisee entrepreneurial autonomy from the franchisee's perspective } \\
\text { Effective for understanding the internal mediator associated with franchisee entrepreneurial autonomy }\end{array}$ \\
\hline Channel theory & Appropriate for studying the internal influencing factors of franchisee entrepreneurial autonomy from the franchisee's perspective \\
\hline Role-based theory & Appropriate for studying the internal influencing factors of franchisee entrepreneurial autonomy from the franchisee's perspective \\
\hline Strategic perspective & Aids understanding of the internal moderators associated with franchisee entrepreneurial autonomy \\
\hline
\end{tabular}


Figure 1. A model of franchisee entrepreneurial autonomy

\section{EXTERNAL INFLUENCING FACTORS}

-Industry effect, local conditions and local market

variations

INTERNAL INFLUENCING FACTORS

(a) Franchisor-drivers

-Franchisor size

-Franchisor support

-Franchisor age

-Franchisor's performance

-Franchised governance structure

-Plural form governance strategy

-Nature of the franchising concept

-Contract range

-Franchisor's intangible assets

tangible assets

-Behavioral uncertainty

-Organizational culture

(b) Franchisee-drivers

-Franchisee ownership structures

-Stages of the franchisee's lifecycle

-Experience of the franchisee

-Success of the franchisee's business

-Personalities and role perception of individual

franchisees

-Partner selection criteria

-Franchisor trust

-Franchisee networks

-Online selling (i.e. franchisee websites)
INTERNAL

MODERATOR

-Trust
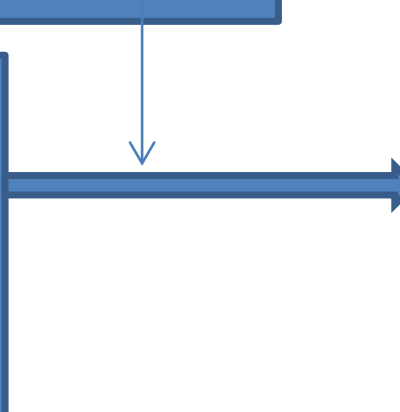

FRANCHISEE ENTREPRENEURIAL AUTONOMY

INTERNAL

MODERATORS

-Franchisee incentive

characteristics
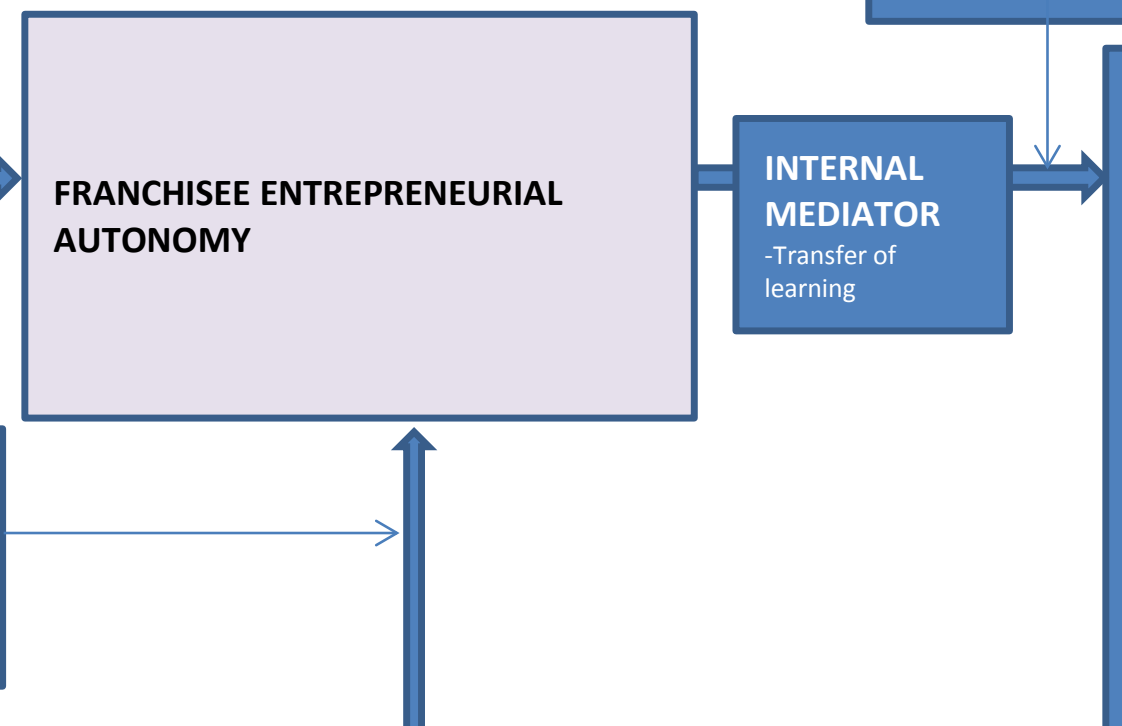

CONTROL MECHANISMS

(a) Formalized control mechanisms exercised by franchisors

-Franchise contract and incentives

-Strictly circumscribed sphere for franchisee entrepreneurial behaviors

-Presence of franchise coordinators and franchise managers from the

franchisor headquarters in franchisee networks

-Franchisor's permission

-Monitoring

-Franchisor's guidelines

-Franchisor mechanisms to capture innovations that assist overall

competitive advantage

-Franchisor learning

-Relational governance

(b) Formalized and social control mechanisms exercised by franchisees

-Franchisee cohesion

-Franchisee representatives
INTERNAL MODERATORS

-HR operational autonomy

-HR operational autonomy
-Franchise contract formal goals

-Franchise contract formal go
POSITIVE OUTCOMES

-Financial and non-financial performance

-System-wide adaptations

Organizational learning

-Competitive advantage

-Franchisee satisfaction

-Franchisor-franchisee relationship quality

-Franchisee opportunism

\section{NEGATIVE OUTCOMES}

-Franchisee failure

-Conflict

-Losses in scale economies

-Franchisee opportunism 